\title{
Orchestrating transcriptional control of adult neurogenesis
}

\author{
Jenny Hsieh ${ }^{1}$ \\ Department of Molecular Biology, University of Texas Southwestern Medical Center, Dallas, Texas 75390, USA
}

\begin{abstract}
Stem cells have captured our imagination and generated hope, representing a source of replacement cells to treat a host of medical conditions. Tucked away in specialized niches, stem cells maintain tissue function and rejuvenate organs. Balancing the equation between cellular supply and demand is especially important in the adult brain, as neural stem cells (NSCs) in two discrete regions, the subgranular zone (SGZ) of the dentate gyrus and the subventricular zone (SVZ) next to the lateral ventricles, continuously self-renew and differentiate into neurons in a process called adult neurogenesis. Through the interplay of intrinsic and extrinsic factors, adult neurogenic niches ensure neuronal turnover throughout life, contributing to plasticity and homeostatic processes in the brain. This review summarizes recent progress on the molecular control of adult neurogenesis in the SGZ and $\mathrm{SVZ}$, focusing on the role of specific transcription factors that mediate the progression from NSCs to lineagecommitted progenitors and, ultimately, the generation of mature neurons and glia.
\end{abstract}

In the adult mammalian brain, new neurons are continuously generated in two anatomical regions: the subgranular zone (SGZ) of the hippocampal dentate gyrus and the subventricular zone (SVZ) lining the lateral ventricles (Altman and Das 1965; Gage 2000; Alvarez-Buylla and Garcia-Verdugo 2002; Ming and Song 2005). To ensure continuous neuronal production while maintaining the neural stem cell (NSC) pool, the sequential steps of adult SGZ and SVZ neurogenesis are regulated by a multicellular neurogenic niche (Doetsch et al. 1999; Palmer et al. 2000; Merkle et al. 2004; Shen et al. 2008). Within the adult SGZ, stem and progenitor cells differentiate into granule neurons, which receive glutamatergic inputs, in addition to astrocytes (Cameron et al. 1993; Kempermann et al. 2004). Adult hippocampal neurogenesis contributes to learning and memory and may also be involved in neuropsychiatric disorders (Noonan et al. 2010; Aimone et al. 2011; Sahay et al. 2011; Snyder et al. 2011; Petrik et al. 2012). NSCs in the SVZ differentiate into mostly

[Keywords: adult neural stem cells; self-renewal; differentiation; niche; hippocampus; subventricular zone; reprogramming]

${ }^{1}$ Correspondence. E-mail jenny.hsieh@utsouthwestern.edu.

Article is online at http://www.genesdev.org/cgi/doi/10.1101/gad.187336.112.
GABAergic as well as glutamatergic and dopaminergic interneurons, which migrate through the rostral migratory stream (RMS) and integrate in the olfactory bulb (OB) (Merkle et al. 2004; Scheffler et al. 2005; Lledo et al. 2008; Brill et al. 2009). Adult-generated olfactory interneurons contribute to odor discrimination and olfactory memory (Mouret et al. 2009; Sakamoto et al. 2011; Kageyama et al. 2012). In some instances, SVZ NSCs can also function as oligodendrocyte progenitors in the adult brain (Menn et al. 2006). Although decades have elapsed between the initial discovery of postnatal mammalian neurogenesis (Altman and Das 1965) and in vitro derivation of multipotent NSCs from the adult mouse brain (Reynolds and Weiss 1992), fundamental information is still lacking, such as the regulatory mechanisms controlling the self-renewal and differentiation of adultgenerated neurons.

Understanding the molecular mechanisms controlling adult neurogenesis has been the focus of recent studies. In the past, much insight has been gained from analyses of the developing brain. In a precise spatial and temporal manner, neural precursors give rise to distinct neuronal subtypes, followed by glial cell generation (McConnell 1989; Guillemot 2007; Okano and Temple 2009). Similar to their embryonic counterparts (Guillemot 2005, 2007), adult NSCs activate intrinsic programs based on the sequential activation of transcription factors. In contrast to embryonic development, adult NSCs self-renew and differentiate in the context of the mature nervous system environment, and adult-generated neurons and glia appear to be produced on demand, rather than on a fixed schedule per se. Extrinsic factors such as environmental, physiological, and pharmacological stimuli modulate adult neurogenesis (van Praag et al. 1999). Interested readers may refer to additional reviews on this topic ( $\mathrm{Mu}$ et al. 2010; Ihrie and Alvarez-Buylla 2011; Ming and Song 2011). However, it is unclear how niche-derived signals and subsequent signaling cascades ultimately influence the expression of specific transcription factors to govern the different stages of adult neurogenesis. Besides the role of transcription factors, additional intrinsic factors that include epigenetic mechanisms such as DNA methylation, histone modification marks, chromatin remodeling, and microRNAs are not discussed here, but readers may refer to several recent reviews (Li and Zhao 2008; Hsieh and Eisch 2010; Ma et al. 2010; Sun et al. 2011; Jiang and Hsieh 2012). 
Below, I present an overview of the neurogenic niche and the specific stages of adult neurogenesis, followed by a description of the role of transcription factors that control adult SGZ and SVZ neurogenesis. I also discuss the possibility of targeting transcriptional networks as an effective strategy to regulate proliferation and differentiation of adult NSCs for therapeutic repair. I end the review by highlighting outstanding questions that will likely be the focus of future studies.

\section{Overview of adult SGZ neurogenesis}

The first region of the adult brain that continues to generate new neurons is the SGZ in the dentate gyrus of the hippocampus (Fig. 1). Within the SGZ niche are populations of stem and progenitor cell types, which vary in their cell division rates. Slowly dividing or quiescent NSCs (type 1) have a single radial process that extends through the GCL and express markers such as glial fibrillary acidic protein (GFAP) and Nestin (Seri et al. 2001; Kempermann et al. 2004; Ables et al. 2010; Mira et al. 2010). Recently, a second class of type 1 cells-characterized by short, horizontal processes-was identified (Lugert et al. 2010). Horizontal type 1 cells appear to divide more quickly; however, the lineage relationship between radial and horizontal type 1 cells is unclear. Once quiescent NSCs proliferate, they divide to generate transit-amplifying progenitors (TAPs) that have the potential to differentiate into neurons and astrocytes (Kronenberg et al. 2003; Kempermann et al. 2004; Lugert et al. 2010; Bonaguidi et al. 2011; Encinas et al. 2011). Morphologically, TAPs are small cells with short tangential processes and are often found in clusters in the SGZ. There are several types of TAPs, which can be identified on the basis of morphology and marker expression (Encinas et al. 2006; Suh et al. 2007; Lugert et al. 2010). The SRY-box transcription factor 2 (Sox2) identifies type 2A cells (as well as type 1 cells), which transition to late stage TAPs (type 2B) or neuroblasts (type 3). The major difference between type $2 \mathrm{~A}$, type $2 \mathrm{~B}$, and type 3 cells is that type $2 \mathrm{~B}$ cells were initially identified in Nestin-GFP reporter mice and expression of the immature neuronal marker doublecortin (DCX) in Nestin-GFP ${ }^{+}$cells defines the transition between type $2 \mathrm{~A}$ and type $2 \mathrm{~B}$, whereas Nestin-negative type 3 cells express DCX only (Dhaliwal and Lagace 2011). Finally, there is down-regulation of DCX and up-regulation of calretinin and $\mathrm{NeuN}$ as immature neurons differentiate into mature glutamatergic granule neurons. Newly generated neurons in SGZ will structurally and functionally mature in $\sim 6-8$ wk (van Praag et al. 2002; Zhao et al. 2006).

Signals arising from the microenvironment, including cellular components (e.g., vascular cells, glial cells, and granule neurons themselves) and noncellular components (e.g., secreted molecules and the extracellular matrix $[\mathrm{ECM}]$ ), influence the activity of SGZ NSCs (Palmer et al. 2000; Ma et al. 2005, 2009; Tavazoie et al. 2008; Morrens et al. 2012). In the niche, both neurons and astrocytes play an instructive role to promote NSC selfrenewal and differentiation (Song et al. 2002; Deisseroth et al. 2004; Tozuka et al. 2005). Several lines of evidence indicate that neural progenitor cells respond to neuronal activity in the form of glutamate and GABA as part of their differentiation program (Deisseroth et al. 2004; Tozuka et al. 2005). In addition to neurotransmitters, astrocytes are also a potential source of classical paracrine
A

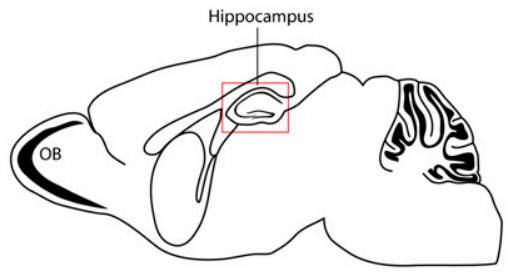

B

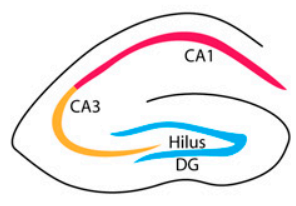

\section{C}

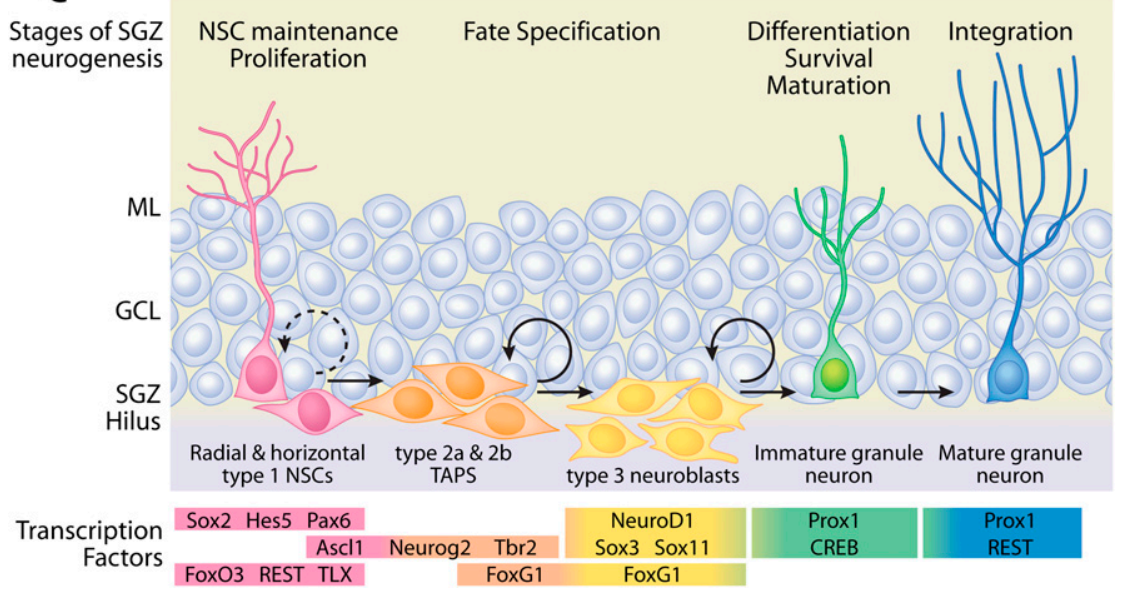

Figure 1. Adult neurogenesis in the SGZ of the dentate gyrus within the hippocampus. (A) Sagittal view of the rodent brain with the boxed region outlining hippocampal formation. (B) Schematic of the hippocampus with CA1, CA3, dentate gyrus (DG), and hilus regions. (C) The SGZ niche is comprised of radial and horizontal type 1 NSCs (pink), early stage type 2a TAPs (orange), late stage type 3 TAPs (yellow), immature granule neurons (green), and mature granule neurons (blue). The progression from type 1 NSCs to mature granule neurons in adult SGZ is a multistep process with distinct stages (labeled on top) and is controlled by the sequential expression of transcription factors (bottom colored panels). (ML) Molecular layer; (GCL) granule cell layer. 
niche factors such as Notch, Sonic hedgehog (Shh), bone morphogenetic proteins (BMPs), and Wnts (Ahn and Joyner 2005; Lie et al. 2005; Ables et al. 2010; Mira et al. 2010). In coculture experiments, astrocytes have been shown to promote neuronal differentiation (Song et al. 2002). Vascular components, including dividing endothelial cells, smooth muscle pericytes, and fibroblasts, as well as microglia, are closely associated with newly generated neurons and may provide instructive cues to NSCs (Palmer et al. 2000; Goldman and Chen 2011). A direct role for endothelial mitogens in promoting neurogenesis was demonstrated in vitro, providing initial evidence that the coassociation of endothelial cells with NSCs may be causal (Shen et al. 2004). Together, these studies support the concept of a multicellular niche to support adult neurogenesis, in which NSCs respond to instructive signals, allowing their proliferative expansion and differentiation into mature cell types. Ultimately, niche-derived signals are relayed to the NSC genome to control transcription of genes involved in self-renewal and differentiation.

\section{Maintenance and cell fate specification of SGZ NSCs}

The transcriptional network governing the production of new neurons in the adult SGZ is relatively unknown compared with embryonic neurogenesis. Next, I present some of the transcription factors that control adult SGZ neurogenesis. However, in only a few cases have loss-offunction and/or gain-of-function studies been performed; thus, a common theme that emerges is that their functional roles are still unclear. To initiate neurogenesis, type 1 cells divide to generate TAPs as they turn on the expression of a series of transcription factors. One transcription factor specifically expressed in SGZ NSCs is the SRY-related HMG box (Sox) family member Sox2, which plays key roles in stem cell self-renewal and development of the nervous system (Lefebvre et al. 2007). Sox2 is expressed in both radial and horizontal GFAP ${ }^{+} / \mathrm{Nestin}^{+}$ type 1 cells (Komitova and Eriksson 2004; Suh et al. 2007; Lugert et al. 2010). In early stage type 2a cells, Sox2 colocalizes with dividing PCNA ${ }^{+}$cells (Ferri et al. 2004). Recently, many studies have taken advantage of conditional and/or inducible mice in adult neurogenesis research (Dhaliwal and Lagace 2011). In this system, a tamoxifen-dependent CreERT2 recombinase driven by a cell-specific promoter/enhancer (Weber et al. 2001) allele is crossed with a floxed allele of the gene of interest (for loss-of-function studies) and/or a reporter gene (e.g., ROSA26RloxP-stop-loxP lacZ or GFP) to allow fate mapping of Cre-recombined reporter ${ }^{+}$cells in the adult SGZ. Conditional deletion of Sox2 in Sox2-expressing adult SGZ NSCs (using Sox2-CreERT2) resulted in depletion of type 1 and type 2 cells and a corresponding decrease of immature $\mathrm{DCX}^{+}$and $\mathrm{BrdU} / \mathrm{NeuN}^{+}$granule neurons, consistent with a critical role of Sox2 in stem cell maintenance (Favaro et al. 2009).

One recent study addressed the interesting question of what controls Sox 2 expression. In the adult SGZ niche, Notch signaling is involved in the maintenance of type 1 cells, as conditional deletion of Notch signaling effectors results in depletion of type 1 cells or precocious differentiation of type 1 and type 2 cells into neurons (Ables et al. 2010; Ehm et al. 2010; Imayoshi et al. 2010). Interestingly, maintenance of Sox 2 expression itself appears to require active Notch signaling, as loss of activated Notch in RBPJk-deficient mice leads to decreased expression of Sox2 (Ehm et al. 2010). It remains unclear whether Sox2 is a direct target of Notch signaling or acts through a parallel pathway. Alternatively, one direct target of Notch signaling is the basic helix-loop-helix (bHLH) transcription factor Hes5, which colocalizes with Sox2 and could cooperate with Sox 2 to control NSC maintenance (Lugert et al. 2010).

The paired domain and homeodomain-containing transcription factor Pax6 is expressed by both radial and horizontal type 1 NSCs as well as early stage type 2 cells. During development, Pax6 is expressed in radial glia (Gotz et al. 1998; Englund et al. 2005; Hodge et al. 2008). Functionally, heterozygote small eye Pax $6^{(\mathrm{Sey} /+)}$ mutant mice display a reduction in $\mathrm{GFAP}^{+}$type 1 cells, including fewer proliferating $\mathrm{GFAP}^{+} / \mathrm{BrdU}^{+}$type 1 cells (Maekawa et al. 2005). While these results suggest that Pax6 may have a role in controlling the adult NSC pool, its definitive role in adult SGZ neurogenesis is still unknown.

In addition to Sox2, Hes5, and Pax6, several additional noteworthy transcription factors are expressed in adult SGZ NSCs. Ascl1, another bHLH transcription factor, is also expressed in both radial and horizontal type 1 NSCs and the majority of type 2 cells (Pleasure et al. 2000; Kim et al. 2007, 2008, 2011; Ables et al. 2010). Tamoxifeninducible fate mapping with an Ascl1CreERT2 knock-in allele was found to specifically mark granule neuron cell types, but not astrocytes or oligodendrocytes (Kim et al. 2007, 2011). Interestingly, overexpression of Ascl1 leads to the generation of oligodendrocytes (Jessberger et al. 2008), suggesting that the level of Ascll is important in controlling fate choice. In spite of these findings, the exact role of Ascll in the context of SGZ neurogenesis has not been determined.

Several recent studies also describe the use of inducible CreERT2 transgenic mouse models to functionally dissect the transcriptional mechanisms that control the SGZ NSC pool. The forkhead domain transcription factor FoxO3 is expressed in Sox $2^{+}$NSCs, and the absence of FoxO3 leads to a failure of NSCs to return to the quiescent state, ultimately leading to the depletion of the NSC pool (Renault et al. 2009). In addition, the RE1 silencing transcription factor (REST), also known as NRSF, functions to repress the neuronal differentiation program in embryonic stem (ES) cells and early embryonic development (Yamada et al. 2010; Mandel et al. 2011; Aoki et al. 2012; Soldati et al. 2012). Recent work from my laboratory found that REST is expressed in type 1 cells, but is down-regulated in a subset of Ascl1 ${ }^{+}$cells and the majority of NeuroD1 ${ }^{+}$cells (Gao et al. 2011). By keeping neuronal genes repressed, REST also serves to preserve the undifferentiated state and maintain the adult NSC pool. Finally, the nuclear hormone transcription factor TLX is strictly required for proliferation of both type 1 and type 2 cells (Niu et al. 2011). Using inducible 
genetic lineage tracing, TLX-expressing cells contribute to both activated (proliferating) and inactive (quiescent) type 1 SGZ NSCs. How do FoxO3, REST, and TLX regulate NSC activation? Genome-wide gene expression analyses in FoxO3- and TLX-deficient NSCs suggest that many genes involved in cell proliferation show significant changes (Zhang et al. 2008; Renault et al. 2009; Niu et al. 2011). One possibility is that FoxO3, TLX, and REST may function in an interconnected transcriptional network or operate in separate pathways.

The transition from radial and horizontal type 1 cells to neuronal lineage-committed TAPs and neuroblasts is marked by the up-regulation of the bHLH transcription factor Neurog2 and the T-box transcription factor Tbr2. The expression of both Neurog2 and Tbr2 begins in a subset of $\operatorname{Sox}^{+} / \mathrm{Pax}^{+} / \mathrm{Ascll}^{+}$type $2 \mathrm{a}$ cells and peaks as TAPs mature into DCX ${ }^{+}$and PSA-NCAM ${ }^{+}$type 3 cells, with Neurog2 expression decreasing prior to Tbr2 (Hodge et al. 2008; Roybon et al. 2009a). While the specific roles of Neurog2 and Tbr2 in adult SGZ are currently unknown, their critical requirement in glutamatergic granule neuron specification during development (Arnold et al. 2008; Roybon et al. 2009a) suggests that they may also play important roles in adult SGZ neurogenesis.

\section{Differentiation, survival, and maturation of dentate granule neurons}

As TAPs commit to neuronal lineages and further differentiate into glutamatergic granule neurons, there is a switch in the transcription factor program to control the later stages of neurogenesis. In line with this, work from several laboratories showed that the bHLH transcription factor NeuroD1 is not detected in the majority of GFAP ${ }^{+}$ type 1 cells, but is only expressed in a rare subset of Sox $2^{+}$ NSCs (Steiner et al. 2006; Gao et al. 2009; Kuwabara et al. 2009). Instead, NeuroD1 expression peaks in late stage $\mathrm{Nestin}^{+} / \mathrm{DCX}^{+}$type $2 \mathrm{~b}$ and $\mathrm{DCX}^{+}$type 3 cells. Conditional deletion of NeuroDl in Nestin ${ }^{+}$adult SGZ NSCs results in fewer adult-generated granule neurons due to the essential role of NeuroD1 in the differentiation and survival of neuronal precursors (Gao et al. 2009). Interestingly, in a subset of NeuroD1-deficient cells, NeuroD1 appears to be required for the maturation of newborn neurons. Kuwabara et al. (2009) demonstrated that NeuroD1 transcription is dependent on Wnt/B-catenin signaling and removal of Sox 2 repression from the NeuroD1 promoter, which is consistent with the downregulation of NeuroD1 in Sox $2^{+}$TAPs.

Sox family transcription factors may also play fundamental roles in the transition of TAPs to immature and mature granule neurons. Sox3, which belongs to the SoxB1 subgroup of Sox factors, is expressed in late stage $\mathrm{DCX}^{+}$type 3 cells and down-regulated in post-mitotic $\mathrm{NeuN}^{+}$granule neurons (Wang et al. 2006). Analogously, Sox11, a member of the SoxC subgroup, is also expressed in $\mathrm{DCX}^{+}$TAPs and neuroblasts and down-regulated in mature neurons (Haslinger et al. 2009). Evidence for a role of Sox11 in adult SGZ neurogenesis comes from the observation that overexpression of Sox 11 is sufficient to promote neuronal differentiation, which is associated with up-regulation of DCX and the neuronal microtubule-associated protein MAP2AB (Haslinger et al. 2009). Interestingly, a recent study described Sox11 as playing an essential role in adult SGZ neurogenesis as well as in reprogramming of astrocytes to neurons, together with Sox4 and Neurog2 (Mu et al. 2012). However, in vivo conditional ablation of Sox 4 and Sox11, while inhibiting neurogenesis, did not alter GFAP expression, suggesting that astrocyte differentiation was unaffected. Hence, the identification of transcription factors required for neuronal versus astrocyte fate in the adult SGZ remains to be determined.

In addition, FoxG1, a Winged-Helix transcriptional repressor, is expressed in TAPs, but not quiescent NSCs (Shen et al. 2006). Functionally, FoxG1 appears to be required for postnatal hippocampus neurogenesis. Besides the substantial reduction of the size of the dentate in FoxG1 haploinsufficient mice, decreased numbers of $\mathrm{BrdU}^{+}$ TAPs and PSA-NCAM ${ }^{+}$type 3 cells due to impaired neuronal differentiation are also observed in FoxG1 ${ }^{+/-}$mice, suggesting that FoxG1 is involved in regulating the progenitor pool as well as maturation of newborn neurons (Shen et al. 2006). However, additional studies of adult NSC-specific deletion of FoxG1 are required to fully explore the cell-autonomous role of FoxG1 in adult SGZ neurogenesis.

Besides NeuroD1, several additional transcription factors have been shown to be necessary for the survival and maturation of newly generated granule neurons. The widely used marker for granule neurons is the prosperorelated homeobox gene Prox1 (Liu et al. 2000), which is first up-regulated in late stage type 3 cells and continues to be expressed in immature as well as mature granule neurons (Jessberger et al. 2008). In addition to being a useful marker of granule neurons, Proxl is required for the survival and maturation of adult-generated neurons (Lavado et al. 2010; Karalay et al. 2011). Conditional deletion of Prox 1 in adult Nestin-expressing NSCs leads to decreased numbers of $\mathrm{DCX}^{+}$and calretinin ${ }^{+}$granule neurons (Lavado et al. 2010), and these results were further confirmed by lentivirus-mediated shRNA knockdown in adult SGZ demonstrating reduced numbers of glutamatergic neurons (Karalay et al. 2011). Similar to NeuroD1, the Prox1 gene is also dependent on Wnt/ $\beta$-catenin signaling, since mutation of the two functional TCF/LEF sites blocks Proxl promoter expression after $\beta$-catenin stimulation in luciferase assays (Karalay et al. 2011). In contrast, knockdown of Proxl using an adenovirus vector in mature neurons apparently does not impact their survival, despite its expression in mature cells, suggesting that Prox1 may play a specific role during neurogenesis.

Finally, the transcription factor cAMP response element-binding protein CREB is also required for the maturation and survival of granule neurons (Jagasia et al. 2009). In terms of its role, overexpression of CREB in progenitor cells enhances the dendritic length and branching on immature neurons, while knockdown has the opposite effect of reducing the number and complexities 
of dendritic branches (Jagasia et al. 2009). Interestingly, there is a reduction in NeuroD $1^{+}$cells; however, whether it is the direct transcriptional target responsible for the reduction in differentiation and survival of adult granule neurons is unknown.

\section{Overview of adult SVZ neurogenesis}

The second region in which neuronal production persists throughout life is within the SVZ of the lateral ventricle (Fig. 2). The adult brain lateral ventricles bear a striking resemblance to the ventricular zone in the embryonic neuroepithelium (McConnell 1989; Guillemot 2005). In the neocortex, radial glia-progenitors with cell bodies close to the ventricles and a long radial process that contacts the pial surface-generate the tremendous diversity of neurons and glia that populate the CNS (Fishell and Kriegstein 2003; Noctor et al. 2007). Viral-tracing studies have shown that a subset of radial glial cells subsequently gives rise to astrocyte-like NSCs (type B1 cells) that serve as slowly cycling stem cells of the SVZ during postnatal and adult stages (Merkle et al. 2004, 2007; Spassky et al. 2005). In addition to their astrocytic morphology and ultrastructure, type B1 cells also express markers associated with astroglia, such as astrocyte-specific glutamate transporter (GLAST), brain-lipid-binding protein (BLBP), GFAP, and nestin (Doetsch et al. 1999; Liu et al. 2006; Nomura et al. 2010). Interestingly, type B1 cells contain a nonmotile primary cilium that extends into the ventricular cerebrospinal fluid (CSF), suggesting a signaling role of the cilium in the regulation of proliferation and differentiation (Doetsch et al. 1999; Mirzadeh et al. 2008;
Shen et al. 2008). In contrast, type B2 cells have astrocytic features, but do not contact the ventricle. Type C cells, the progeny of type B cells, rapidly proliferate and are often found in clusters near blood vessels (Kriegstein and Alvarez-Buylla 2009). Similar to type 2 TAPs in the SGZ, type C cells up-regulate Ascl1, Pax6, and the transcription factor Dlx2 (Brill et al. 2008). Finally, type C cells give rise to type A neuroblasts, which form migratory chains encased within astrocyte tubes (Lois et al. 1996). Over the course of $3 \mathrm{wk}$, these multiple progenitor cell types ultimately give rise to a diverse array of neurons, including deep granule interneurons and calbindin ${ }^{+}$periglomerular cells (from ventral/medial SVZ progenitors) and superficial granule interneurons and calretinin ${ }^{+}$periglomerular cells (from dorsal/anterior SVZ progenitors) (Merkle et al. 2007; Lledo et al. 2008). Most of the OB neurons are GABAergic interneurons; however, a recent fate-mapping study suggested the existence of glutamateric juxtaglomerular neurons (Brill et al. 2009), leaving open the question how SVZ NSCs contribute to distinct neuronal subtypes.

Multiple lines of evidence suggest that the planar architecture of the SVZ niche is important to control the behavior of NSCs (Doetsch et al. 1997; Ihrie and AlvarezBuylla 2011). The small apical processes of SVZ NSCs (known as primary cilium) are surrounded by a rosette of ependymal cells (Mirzadeh et al. 2008). Here, contacts between type B NSCs and neighboring ependymal cells, the CSF, and the vasculature are especially important to maintain self-renewal and proliferation (Ihrie and Alvarez-Buylla 2011). Within the SVZ niche, ependymal cells are multiciliated, raising several possibilities regarding
A

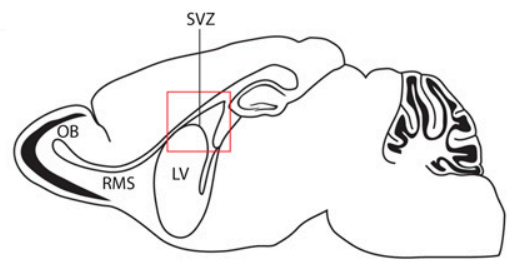

B

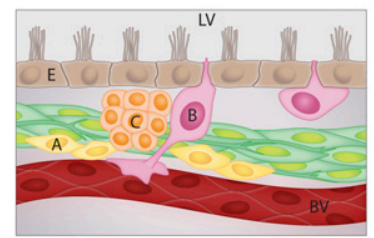

C

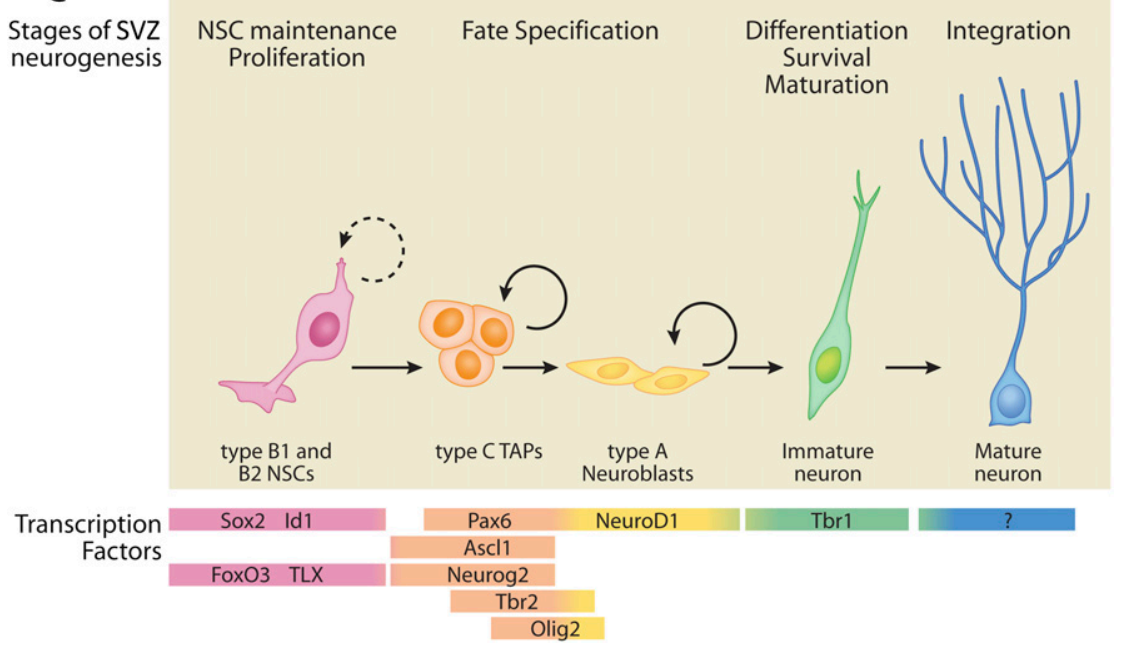

Figure 2. Adult neurogenesis in the SVZ and RMS. (A) Sagittal view of the rodent brain, with the boxed region outlining the SVZ region next to the lateral ventricle (LV). (B) Schematic of the SVZ with ependymal cells (E), blood vessel cells (BV), and distinct stem/progenitor cell types (types B, C, and A). (C) The SVZ niche is comprised of astrocyte-like type B1 and B2 NSCs (pink), type C TAPs (orange), type A neuroblasts (yellow), immature neurons (green), and mature neurons (blue). The progression from type B NSCs to mature neurons in the adult SVZ is a multistep process with distinct stages (labeled on top) and is controlled by the sequential expression of transcription factors (bottom colored panels). 
the role of cilia in controlling stem cell activity. These motile cilia are slanted in the direction of CSF, which contributes to its flow and creates gradients of Slit chemorepellents that guide anterior neuroblast migration from the SVZ to the OB (Nguyen-Ba-Charvet et al. 2004; Sawamoto et al. 2006). Besides affecting the direction of flow, these motile cilia may also function in an antennalike fashion, receiving factors from CSF such as Hedgehog, Wnt, and PDGF signals, which are thought to be important in this region (Corbit et al. 2005; Jackson et al. 2006; Adachi et al. 2007; Rohatgi et al. 2007). Ependymal cells also express the BMP inhibitor Noggin, which promotes differentiation at the expense of self-renewal and proliferation (Lim et al. 2000). Besides ependymal cells, the ECM and vascular components are important components of the SVZ niche (Kazanis et al. 2010). The basal face of the SVZ is comprised of an extensive basement membrane and the ECM, which is composed of laminin, heparan sulfate proteoglycans, and tenascin-C, and contacts SVZ cell types (Mercier et al. 2002; Shen et al. 2008; Kazanis et al. 2010). Similar to the SGZ, the adult SVZ also harbors extensive vasculature and close proximity of clusters of proliferating NSCs closely associated with blood vessels (Shen et al. 2008; Tavazoie et al. 2008). Evidence from recent work has shown that blood vessels provide signals to NSCs for their proliferation and differentiation, in addition to serving as a scaffold for neuroblast migration (Snapyan et al. 2009; Whitman et al. 2009; Kokovay et al. 2010). Collectively, these studies highlight the importance of a multicellular niche to regulate the self-renewal and differentiation of adult SVZ NSCs.

\section{Maintenance and cell fate specification of SVZ NSCs}

Together, extracellular signaling pathways within the SVZ niche and intrinsic programs-including transcription factors and nuclear receptors-have also been reported to control SVZ NSC self-renewal and differentiation. Given the fact that SVZ NSCs give rise to both GABAergic and glutamatergic lineages, it is not surprising that adult SVZ and SGZ neurogenesis is dictated by overlapping transcriptional programs. Sox2 is expressed in TAPs of the SVZ, and loss of Sox2 leads to a marked decrease in proliferating progenitors and reduction of $\mathrm{DCX}^{+}$neuroblasts (Ferri et al. 2004; Brill et al. 2009; Roybon et al. 2009a). Interestingly, a recent study demonstrated that the zinc finger protein Ars2 (arsenite-resistance protein 2) is a critical transcriptional activator of Sox2 to maintain adult SVZ NSCs (Andreu-Agullo et al. 2012). Ars2 was previously known for its conserved role in microRNA biogenesis (Yang et al. 2006; Laubinger et al. 2008; Gruber et al. 2009; Sabin et al. 2009). However, this study highlights an RNA-independent role of Ars2 in stem cell maintenance. In addition to Sox2 and similar to SGZ NSCs, FoxO3 and TLX are both expressed in type B SVZ NSCs and appear to be required for their proliferation and maintenance (Zhang et al. 2008; Renault et al. 2009; Niu et al. 2011). Interestingly, Tlx may mediate the repression of cell cycle inhibitory factors through the recruitment of the Polycomb group protein Bmi-1 as well as a host of other tumor suppressor genes, including the p53 and PTEN pathways (Sun et al. 2007; Liu et al. 2008, 2010). Incidentally, Bmil-null mice have impaired self-renewal of adult SVZ NSCs (Molofsky et al. 2003).

Adult SVZ NSCs also appear to be under the control of negative regulators, such as the inhibitor of DNA-binding (Id) genes, which encode dominant-negative antagonists of the bHLH transcription factors such as E47 (Benezra et al. 1990). Recent work using immunofluorescence and genetic fate mapping show that high levels of Id1 are found in bona fide type B1 SVZ NSCs that give rise to the SVZ neurogenic lineage. What is particularly interesting is that a gradient of Id1 expression (from high to low) appears to be important in controlling SVZ NSC selfrenewal, at least in the context of in vitro neurosphere assays (Nam and Benezra 2009). In vivo deletion of Id1 or Id3, however, does not seem to have a major phenotype, suggesting redundancy or compensatory mechanisms. Whether acute deletion of Id 1 affects adult neurogenesis remains to be determined.

As type B NSCs transition to type C TAPs, Ascll expression is transiently up-regulated and coexpressed in a subset of progenitors with Neurog2. Ascll is important to mediate both GABAergic and glutamatergic neuronal phenotypes (Brill et al. 2009). One unique aspect of SVZ NSCs that distinguishes them from precursors in the SGZ is the ability of glial-restricted progenitors to migrate radially from the SVZ in the subcortical white matter, corpus callosum, striatum, and various cortical areas, where they differentiate into astrocytes and oligodendrocytes (Marshall and Goldman 2002). The bHLH transcription factor Olig2 is expressed in a subset of SVZ NSCs and appears to be necessary and sufficient to prevent neuronal differentiation and direct SVZ progenitors toward astrocytic and oligodendrocytic fates (Marshall et al. 2005).

More recently, it was discovered that the dorsal region of the SVZ contains a distinct progenitor population that transiently expresses Neurog2 and Tbr2 and gives rise to glutamatergic neurons of the OB (Brill et al. 2009). Currently, it is unclear whether Neurog2 and Tbr2 play functional roles in adult SVZ neurogenesis. Overexpression of Neurog2 in Ascl1 ${ }^{+}$SVZ progenitors in vitro induced the generation of calretinin ${ }^{+}$neurons and down-regulated Ascll expression (Roybon et al. 2009b), but the specific role of Neurog2 in adult SVZ neurogenesis has yet to be identified. Conditional inactivation of Tbr2 in the early embryo results in deficits in cortical SVZ neurogenesis and a complete absence of adult hippocampal neurogenesis. However, Tbr2 does not appear to be required for the establishment of adult SVZ progenitors, since DCX staining in the RMS appears normal (Arnold et al. 2008). Along these lines, Tbr2 expression is down-regulated as neuroblasts exit the cell cycle in the RMS, but is maintained in glutamatergic neurons in the embryo and early postnatal stages, suggesting that there may be important contextual differences between the embryo and adult environment (Winpenny et al. 2011). Interestingly, Ascl1 is coexpressed with Pax6 in most type C SVZ progenitors and mediates the GABAergic phenotype, 
while coexpression of Ascl1 and Neurog2 is important for the glutamatergic lineage (Brill et al. 2009; Roybon et al. 2009a). In contrast, coexpression of Ascl1 and Olig2 is required for the oligodendrocyte lineage, suggesting that $\mathrm{Ascl1}^{+} \mathrm{SVZ}$ progenitors are bipotent, with the ability to give rise to both neurons and oligodendrocytes (Parras et al. 2004; Roybon et al. 2009a). How different transcription factors cross-talk with each other to specify individual neuronal and glial subtypes remains to be determined.

\section{Differentiation, survival, and maturation of $O B$ neurons}

To control the later stages of SVZ neurogenesis, NeuroD1 begins to be expressed in Tbr2 ${ }^{+}$TAPs, and its expression is increased in $\mathrm{Tbr}^{+}$neuroblasts in the RMS (Roybon et al. 2009b). While conditional deletion of NeuroD1 in Nestin $^{+}$NSCs leads to decreased numbers of OB cells (Gao et al. 2009), the identity of the NeuroD1-deficient cells is still unknown. Consistent with the role of NeuroD1 in the differentiation and/or survival of OB neurons, a recent study used NeuroD1-specific shRNAs to knock down NeuroD1 levels and found a loss of GABAergic neurons in the OB (Boutin et al. 2010). Tbrl expression is transiently expressed in late stage neuroblasts and immature neurons during SVZ neurogenesis. Most $\mathrm{Tbrl}^{+}$ neuroblasts are post-mitotic and coexpress DCX. From lineage-tracing studies. Tbr $1^{+}$neuroblasts eventually become short axon periglomerular neurons (Brill et al. 2009). Future studies with conditional knockout alleles will determine whether there is a hierarchy of transcription factors required to promote $\mathrm{OB}$ neurogenesis or whether there are separate or redundant transcription programs underlying lineage-specific and context-dependent neuronal differentiation in adult neurogenic niches.

\section{Challenges and strategies for nervous system repair}

As mentioned in the beginning of this review, the capacity to self-renew gives adult NSCs the potential to treat a variety of human neurological conditions, including neurodegenerative diseases, stroke, and epilepsy (Lindvall et al. 2004; Parent et al. 2007; Kernie and Parent 2010). Ultimately, stem cell therapy is likely to be a combination of exogenous stem cell transplantation and endogenous stem cell fate conversion (Lindvall et al. 2004; Goldman 2005). The pioneering work of Blau et al. (1985) and, more recently, Takahashi and Yamanaka (2006) has illustrated that reprogramming of differentiated cell types to stem-like cells or, alternatively, from one lineage cell type directly into a different lineage cell type is achievable. To exploit the utility of transcription factor reprogramming for nervous system repair, there are several overarching questions that need to be addressed.

First, what is the desired cell of origin? Reprogramming glia (e.g., astrocytes or oligodendrocytes) as an endogenous cellular source for neuronal repair may be desirable, since there are many glial progenitors that become activated and proliferate after injury (Kondo and Raff 2000; Mangin and Gallo 2011; Robel et al. 2011).
Second, will astrocyte- or oligodendrocyte-derived neurons successfully establish functional presynaptic outputs and be able to participate in a neural network? Indeed, previous studies have shown that astrocytes in culture can be reprogrammed to adopt neuronal fates after overexpression of Pax 6 alone or the combination of Neurog2 and Ascl1 (Heins et al. 2002; Berninger et al. 2007). In particular, transduction of Neurog2 and Ascll in cortical-derived astroglia resulted in the generation of neuronal cells that fired action potentials and established functional synaptic connections (Berninger et al. 2007; Heinrich et al. 2010). However, it remains unclear whether these in vitro generated cells will be capable of integrating into in vivo circuits.

Third, even if reprogrammed glia-derived neurons were achieved with the delivery of specific transcription factors, would they generate the correct neuronal subtypes? Region-specific fate restriction appears to occur through intrinsic mechanisms. For example, cortical astrocytes from cerebral cortex, a region derived from the dorsal telencephalon, may be restricted toward glutamatergic neuronal fates (Heinrich et al. 2010). Therefore, the question of whether reprogramming with neurogenic transcription factors (or the removal of transcriptional repressors such as REST) can overcome this region-specific bias to generate both glutamatergic and GABAergic neurons may be critical for restoring the balance in a damaged nervous system.

One final important question is whether reprogrammed neurons will be compatible with the host once they are integrated into mature neural circuits. Recently, the reprogramming of fibroblasts from Rett syndrome and schizophrenia patients into human induced pluripotent stem cells (iPSCs) has provided potential new avenues to model disease pathogenesis (Marchetto et al. 2010; Brennand et al. 2011). Moreover, iPSCs derived from patients may provide platforms for high-throughput drug screening. Despite these exciting findings, iPSCs are not completely equal to ES cells in various ways, such as in their gene expression signatures, copy number variation, coding mutations, and epigenetic modifications, which could affect immune tolerance (Zhao et al. 2011). For example, genomewide DNA methylome analysis has demonstrated differences in DNA methylation between ES cells and iPSCs, which may have an impact on gene expression and genomic stability (Lister et al. 2011). Clearly, these important differences need further exploration before translating iPSCs to the clinical setting.

\section{Concluding remarks}

In summary, adult SGZ and SVZ neurogenesis is regulated at two general levels: (1) niche-derived cell-extrinsic factors that signal in an autocrine and/or paracrine manner and (2) integration of niche-derived signals by transcription factors to control NSC self-renewal and differentiation. Each of these mechanisms and their associated networks are used to varying degrees during different stages of adult NSC self-renewal and differentiation. Despite the ability of the brain to activate adult 
SGZ and SVZ NSCs, these collective endogenous mechanisms are still inadequate to fully restore neuronal production and function to the adult nervous system following damage or injury. A set of therapeutic targets will involve strategies for preserving the NSC pool, directing NSCs and TAPs to adopt a neuronal fate, suppressing glial fates, and promoting differentiation and survival of immature neurons. While this review describes a subset of transcription factors controlling adult neurogenesis and discusses possible therapeutic strategies involving adult NSCs, there is still abundant information to be gained.

Toward the future, additional studies focusing on the basic anatomy of the niche, the intrinsic properties of adult SGZ and SVZ NSCs, and the application of discoveries in model organisms to our knowledge of postnatal and adult neurogenesis in humans will guide our efforts to harness the potential of adult NSCs for therapy. For example, studies that define the anatomical components and constraints of the niche will be informative to identify signals that instruct differentiation versus maintain the structural integrity of the niche. Also, a better understanding of the intrinsic properties of NSCs, including how many times a single NSC divides, how many divisions are self-renewing, and whether NSCs are depleted over time, will add to our knowledge of the lineage and long-term self-renewal of single NSCs. Strikingly, one recent report using a low dose of tamoxifen in Nestin-CreERT2; Z/EG reporter mice (which express GFP upon Cre-mediated excision) to achieve sparse labeling of $\mathrm{Nestin}^{+}$neural progenitors in the SGZ demonstrated that a subset of single type 1 cells went through three rounds of division and three modes of selfrenewal and that many type 1 cells were depleted over time, but some were maintained over a 12-mo period (Bonaguidi et al. 2011). Using a complementary genetic inducible model, type 1 NSCs also appeared to self-renew a finite number of times before differentiating into terminal astrocytes over an extended period of time (Encinas et al. 2011). Finally, more work is needed to examine the direct links between adult SGZ and SVZ neurogenesis in rodents and humans. Recent studies have examined the extent of neurogenesis in the human hippocampus and SVZ (Knoth et al. 2010; Sanai et al. 2011; Wang et al. 2011). Together, these studies point to an age-related decrease in SGZ and SVZ neurogenesis, consistent with the evidence in rodents. Hence, our ability to preserve function in damaged or aging brains will benefit from a full understanding of the transcriptional mechanisms controlling adult SGZ and SVZ neurogenesis. Combining the knowledge of transcriptional programs underlying adult neurogenesis and advances in genetic, imaging, and biochemical tools will lead to the most compelling pharmacological interventions that tap into the potential of adult NSCs.

\section{Acknowledgments}

I thank Amelia Eisch, Ondine Cleaver, and Chun-li Zhang for helpful comments on the manuscript, and Jose Cabrera for illustrations. This work was supported by the National Institutes of Health grants R01 AG032383, R01 NS076775, and R21 MH09471501; the Cancer Prevention and Research Institute of Texas grant (RP100674); and the Welch Foundation (I-1660).

\section{References}

Ables JL, Decarolis NA, Johnson MA, Rivera PD, Gao Z, Cooper DC, Radtke F, Hsieh J, Eisch AJ. 2010. Notch1 is required for maintenance of the reservoir of adult hippocampal stem cells. I Neurosci 30: 10484-10492.

Adachi K, Mirzadeh Z, Sakaguchi M, Yamashita T, Nikolcheva T, Gotoh Y, Peltz G, Gong L, Kawase T, Alvarez-Buylla A, et al. 2007. $\beta$-Catenin signaling promotes proliferation of progenitor cells in the adult mouse subventricular zone. Stem Cells 25: 2827-2836.

Ahn S, Joyner AL. 2005. In vivo analysis of quiescent adult neural stem cells responding to Sonic hedgehog. Nature 437: 894-897.

Aimone JB, Deng W, Gage FH. 2011. Resolving new memories: A critical look at the dentate gyrus, adult neurogenesis, and pattern separation. Neuron 70: 589-596.

Altman J, Das GD. 1965. Autoradiographic and histological evidence of postnatal hippocampal neurogenesis in rats. I Comp Neurol 124: 319-335.

Alvarez-Buylla A, Garcia-Verdugo JM. 2002. Neurogenesis in adult subventricular zone. I Neurosci 22: 629-634.

Andreu-Agullo C, Maurin T, Thompson CB, Lai EC. 2012. Ars2 maintains neural stem-cell identity through direct transcriptional activation of Sox2. Nature 481: 195-198.

Aoki H, Hara A, Era T, Kunisada T, Yamada Y. 2012. Genetic ablation of Rest leads to in vitro-specific derepression of neuronal genes during neurogenesis. Development 139: 667-677.

Arnold SJ, Huang GJ, Cheung AF, Era T, Nishikawa S, Bikoff EK, Molnar Z, Robertson EJ, Groszer M. 2008. The T-box transcription factor Eomes/Tbr2 regulates neurogenesis in the cortical subventricular zone. Genes Dev 22: 2479-2484.

Benezra R, Davis RL, Lockshon D, Turner DL, Weintraub H. 1990. The protein Id: A negative regulator of helix-loophelix DNA binding proteins. Cell 61: 49-59.

Berninger B, Costa MR, Koch U, Schroeder T, Sutor B, Grothe B, Gotz M. 2007. Functional properties of neurons derived from in vitro reprogrammed postnatal astroglia. I Neurosci 27: 8654-8664.

Blau HM, Pavlath GK, Hardeman EC, Chiu CP, Silberstein L, Webster SG, Miller SC, Webster C. 1985. Plasticity of the differentiated state. Science 230: 758-766.

Bonaguidi MA, Wheeler MA, Shapiro JS, Stadel RP, Sun GJ, Ming GL, Song H. 2011. In vivo clonal analysis reveals selfrenewing and multipotent adult neural stem cell characteristics. Cell 145: 1142-1155.

Boutin C, Hardt O, de Chevigny A, Core N, Goebbels S, Seidenfaden R, Bosio A, Cremer H. 2010. NeuroD1 induces terminal neuronal differentiation in olfactory neurogenesis. Proc Natl Acad Sci 107: 1201-1206.

Brennand KJ, Simone A, Jou J, Gelboin-Burkhart C, Tran N, Sangar S, Li Y, Mu Y, Chen G, Yu D, et al. 2011. Modelling schizophrenia using human induced pluripotent stem cells. Nature 473: 221-225.

Brill MS, Snapyan M, Wohlfrom H, Ninkovic J, Jawerka M, Mastick GS, Ashery-Padan R, Saghatelyan A, Berninger B, Gotz M. 2008. A Dlx2- and Pax6-dependent transcriptional code for periglomerular neuron specification in the adult olfactory bulb. I Neurosci 28: 6439-6452.

Brill MS, Ninkovic J, Winpenny E, Hodge RD, Ozen I, Yang R, Lepier A, Gascon S, Erdelyi F, Szabo G, et al. 2009. Adult generation of glutamatergic olfactory bulb interneurons. Nat Neurosci 12: 1524-1533.

Cameron HA, Woolley CS, McEwen BS, Gould E. 1993. Differentiation of newly born neurons and glia in the dentate gyrus of the adult rat. Neuroscience 56: 337-344. 
Corbit KC, Aanstad P, Singla V, Norman AR, Stainier DY, Reiter JF. 2005. Vertebrate Smoothened functions at the primary cilium. Nature 437: 1018-1021.

Deisseroth K, Singla S, Toda H, Monje M, Palmer TD, Malenka RC. 2004. Excitation-neurogenesis coupling in adult neural stem/progenitor cells. Neuron 42: 535-552.

Dhaliwal J, Lagace DC. 2011. Visualization and genetic manipulation of adult neurogenesis using transgenic mice. Eur I Neurosci 33: 1025-1036.

Doetsch F, Garcia-Verdugo JM, Alvarez-Buylla A. 1997. Cellular composition and three-dimensional organization of the subventricular germinal zone in the adult mammalian brain. I Neurosci 17: 5046-5061.

Doetsch F, Caille I, Lim DA, Garcia-Verdugo JM, Alvarez-Buylla A. 1999. Subventricular zone astrocytes are neural stem cells in the adult mammalian brain. Cell 97: 703-716.

Ehm O, Goritz C, Covic M, Schaffner I, Schwarz TJ, Karaca E, Kempkes B, Kremmer E, Pfrieger FW, Espinosa L, et al. 2010. $\mathrm{RBPJ \kappa}$-dependent signaling is essential for long-term maintenance of neural stem cells in the adult hippocampus. I Neurosci 30: 13794-13807.

Encinas JM, Vaahtokari A, Enikolopov G. 2006. Fluoxetine targets early progenitor cells in the adult brain. Proc Natl Acad Sci 103: 8233-8238.

Encinas JM, Michurina TV, Peunova N, Park JH, Tordo J, Peterson DA, Fishell G, Koulakov A, Enikolopov G. 2011. Division-coupled astrocytic differentiation and age-related depletion of neural stem cells in the adult hippocampus. Cell Stem Cell 8: 566-579.

Englund C, Fink A, Lau C, Pham D, Daza RA, Bulfone A Kowalczyk T, Hevner RF. 2005. Pax6, Tbr2, and Tbr1 are expressed sequentially by radial glia, intermediate progenitor cells, and postmitotic neurons in developing neocortex. I Neurosci 25: 247-251.

Favaro R, Valotta M, Ferri AL, Latorre E, Mariani J, Giachino C, Lancini C, Tosetti V, Ottolenghi S, Taylor V, et al. 2009. Hippocampal development and neural stem cell maintenance require Sox2-dependent regulation of Shh. Nat Neurosci 12: 1248-1256.

Ferri AL, Cavallaro M, Braida D, Di Cristofano A, Canta A, Vezzani A, Ottolenghi S, Pandolfi PP, Sala M, DeBiasi S, et al. 2004. Sox 2 deficiency causes neurodegeneration and impaired neurogenesis in the adult mouse brain. Development 131: 3805-3819.

Fishell G, Kriegstein AR. 2003. Neurons from radial glia: The consequences of asymmetric inheritance. Curr Opin Neurobiol 13: 34-41.

Gage FH. 2000. Mammalian neural stem cells. Science 287: $1433-1438$.

Gao Z, Ure K, Ables JL, Lagace DC, Nave KA, Goebbels S, Eisch AJ, Hsieh J. 2009. Neurodl is essential for the survival and maturation of adult-born neurons. Nat Neurosci 12: 10901092.

Gao Z, Ure K, Ding P, Nashaat M, Yuan L, Ma J, Hammer RE, Hsieh J. 2011. The master negative regulator REST/NRSF controls adult neurogenesis by restraining the neurogenic program in quiescent stem cells. J Neurosci 31: 9772-9786.

Goldman S. 2005. Stem and progenitor cell-based therapy of the human central nervous system. Nat Biotechnol 23: 862-871.

Goldman SA, Chen Z. 2011. Perivascular instruction of cell genesis and fate in the adult brain. Nat Neurosci 14: 13821389.

Gotz M, Stoykova A, Gruss P. 1998. Pax6 controls radial glia differentiation in the cerebral cortex. Neuron 21: 10311044.
Gruber JJ, Zatechka DS, Sabin LR, Yong J, Lum JJ, Kong M, Zong WX, Zhang Z, Lau CK, Rawlings J, et al. 2009. Ars2 links the nuclear cap-binding complex to RNA interference and cell proliferation. Cell 138: 328-339.

Guillemot F. 2005. Cellular and molecular control of neurogenesis in the mammalian telencephalon. Curr Opin Cell Biol 17: 639-647.

Guillemot F. 2007. Cell fate specification in the mammalian telencephalon. Prog Neurobiol 83: 37-52.

Haslinger A, Schwarz TJ, Covic M, Chichung Lie D. 2009. Expression of Sox11 in adult neurogenic niches suggests a stage-specific role in adult neurogenesis. Eur J Neurosci 29: 2103-2114.

Heinrich C, Blum R, Gascon S, Masserdotti G, Tripathi P, Sanchez R, Tiedt S, Schroeder T, Gotz M, Berninger B. 2010. Directing astroglia from the cerebral cortex into subtype specific functional neurons. PLoS Biol 8: e1000373. doi: 10.1371/journal.pbio.1000373.

Heins N, Malatesta P, Cecconi F, Nakafuku M, Tucker KL, Hack MA, Chapouton P, Barde YA, Gotz M. 2002. Glial cells generate neurons: The role of the transcription factor Pax6. Nat Neurosci 5: 308-315.

Hodge RD, Kowalczyk TD, Wolf SA, Encinas JM, Rippey C, Enikolopov G, Kempermann G, Hevner RF. 2008. Intermediate progenitors in adult hippocampal neurogenesis: Tbr2 expression and coordinate regulation of neuronal output. J Neurosci 28: 3707-3717.

Hsieh J, Eisch AJ. 2010. Epigenetics, hippocampal neurogenesis, and neuropsychiatric disorders: Unraveling the genome to understand the mind. Neurobiol Dis 39: $73-84$.

Ihrie RA, Alvarez-Buylla A. 2011. Lake-front property: A unique germinal niche by the lateral ventricles of the adult brain. Neuron 70: 674-686.

Imayoshi I, Sakamoto M, Yamaguchi M, Mori K, Kageyama R. 2010. Essential roles of Notch signaling in maintenance of neural stem cells in developing and adult brains. I Neurosci 30: 3489-3498.

Jackson EL, Garcia-Verdugo JM, Gil-Perotin S, Roy M, QuinonesHinojosa A, VandenBerg S, Alvarez-Buylla A. 2006. PDGFR $\alpha$ positive B cells are neural stem cells in the adult SVZ that form glioma-like growths in response to increased PDGF signaling. Neuron 51: 187-199.

Jagasia R, Steib K, Englberger E, Herold S, Faus-Kessler T, Saxe M, Gage FH, Song H, Lie DC. 2009. GABA-cAMP response element-binding protein signaling regulates maturation and survival of newly generated neurons in the adult hippocampus. J Neurosci 29: 7966-7977.

Jessberger S, Toni N, Clemenson GD Jr, Ray J, Gage FH. 2008. Directed differentiation of hippocampal stem/progenitor cells in the adult brain. Nat Neurosci 11: 888-893.

Jiang Y, Hsieh J. 2012. Harnessing adult neurogenesis by cracking the epigenetic code. Future Neuro 7: 65-79.

Kageyama R, Imayoshi I, Sakamoto M. 2012. The role of neurogenesis in olfaction-dependent behaviors. Behav Brain Res 227: 459-463.

Karalay O, Doberauer K, Vadodaria KC, Knobloch M, Berti L, Miquelajauregui A, Schwark M, Jagasia R, Taketo MM, Tarabykin V, et al. 2011. Prospero-related homeobox 1 gene (Prox1) is regulated by canonical Wnt signaling and has a stage-specific role in adult hippocampal neurogenesis. Proc Nat1 Acad Sci 108: 5807-5812.

Kazanis I, Lathia JD, Vadakkan TJ, Raborn E, Wan R, Mughal MR, Eckley DM, Sasaki T, Patton B, Mattson MP, et al. 2010. Quiescence and activation of stem and precursor cell populations in the subependymal zone of the mammalian brain are associated with distinct cellular and extracellular matrix signals. J Neurosci 30: 9771-9781. 
Kempermann G, Jessberger S, Steiner B, Kronenberg G. 2004. Milestones of neuronal development in the adult hippocampus. Trends Neurosci 27: 447-452.

Kernie SG, Parent JM. 2010. Forebrain neurogenesis after focal Ischemic and traumatic brain injury. Neurobiol Dis 37: 267-274.

Kim EJ, Leung CT, Reed RR, Johnson JE. 2007. In vivo analysis of Ascll defined progenitors reveals distinct developmental dynamics during adult neurogenesis and gliogenesis. I Neurosci 27: 12764-12774.

Kim EJ, Battiste J, Nakagawa Y, Johnson JE. 2008. Ascl1 (Mash1) lineage cells contribute to discrete cell populations in CNS architecture. Mol Cell Neurosci 38: 595-606.

Kim EJ, Ables JL, Dickel LK, Eisch AJ, Johnson JE. 2011. Ascl1 (Mash1) defines cells with long-term neurogenic potential in subgranular and subventricular zones in adult mouse brain. PLOS ONE 6: e18472. doi: 10.1371/journal.pone.0018472.

Knoth R, Singec I, Ditter M, Pantazis G, Capetian P, Meyer RP, Horvat V, Volk B, Kempermann G. 2010. Murine features of neurogenesis in the human hippocampus across the lifespan from 0 to 100 years. PLOS ONE 5: e8809. doi: 10.1371/ journal.pone.0008809.

Kokovay E, Goderie S, Wang Y, Lotz S, Lin G, Sun Y, Roysam B, Shen Q, Temple S. 2010. Adult SVZ lineage cells home to and leave the vascular niche via differential responses to SDF1/CXCR4 signaling. Cell Stem Cell 7: 163-173.

Komitova M, Eriksson PS. 2004. Sox-2 is expressed by neural progenitors and astroglia in the adult rat brain. Neurosci Lett 369: $24-27$.

Kondo T, Raff M. 2000. Oligodendrocyte precursor cells reprogrammed to become multipotential CNS stem cells. Science 289: $1754-1757$.

Kriegstein A, Alvarez-Buylla A. 2009. The glial nature of embryonic and adult neural stem cells. Annu Rev Neurosci 32: 149-184.

Kronenberg G, Reuter K, Steiner B, Brandt MD, Jessberger S, Yamaguchi M, Kempermann G. 2003. Subpopulations of proliferating cells of the adult hippocampus respond differently to physiologic neurogenic stimuli. J Comp Neurol 467: 455-463.

Kuwabara T, Hsieh J, Muotri A, Yeo G, Warashina M, Lie DC, Moore L, Nakashima K, Asashima M, Gage FH. 2009. Wntmediated activation of NeuroD1 and retroelements during adult neurogenesis. Nat Neurosci 12: 1097-1105.

Laubinger S, Sachsenberg T, Zeller G, Busch W, Lohmann JU, Ratsch G, Weigel D. 2008. Dual roles of the nuclear capbinding complex and SERRATE in pre-mRNA splicing and microRNA processing in Arabidopsis thaliana. Proc Natl Acad Sci 105: 8795-8800.

Lavado A, Lagutin OV, Chow LM, Baker SJ, Oliver G. 2010. Proxl is required for granule cell maturation and intermediate progenitor maintenance during brain neurogenesis. PLOS Biol 8: e1000460. doi: 10.1371/journal.pbio.1000460.

Lefebvre V, Dumitriu B, Penzo-Mendez A, Han Y, Pallavi B. 2007. Control of cell fate and differentiation by Sry-related high-mobility-group box (Sox) transcription factors. Int I Biochem Cell Biol 39: 2195-2214.

Li X, Zhao X. 2008. Epigenetic regulation of mammalian stem cells. Stem Cells Dev 17: 1043-1052.

Lie DC, Colamarino SA, Song HJ, Desire L, Mira H, Consiglio A, Lein ES, Jessberger S, Lansford H, Dearie AR, et al. 2005. Wnt signalling regulates adult hippocampal neurogenesis. Nature 437: 1370-1375.

Lim DA, Tramontin AD, Trevejo JM, Herrera DG, Garcia-Verdugo JM, Alvarez-Buylla A. 2000. Noggin antagonizes BMP signaling to create a niche for adult neurogenesis. Neuron 28: 713-726.
Lindvall O, Kokaia Z, Martinez-Serrano A. 2004. Stem cell therapy for human neurodegenerative disorders-how to make it work. Nat Med 10: S42-S50. doi: 10.1038/nm1064.

Lister R, Pelizzola M, Kida YS, Hawkins RD, Nery JR, Hon G, Antosiewicz-Bourget J, O'Malley R, Castanon R, Klugman S, et al. 2011. Hotspots of aberrant epigenomic reprogramming in human induced pluripotent stem cells. Nature 471: 68-73.

Liu M, Pleasure SJ, Collins AE, Noebels JL, Naya FJ, Tsai MJ, Lowenstein DH. 2000. Loss of BETA2/NeuroD leads to malformation of the dentate gyrus and epilepsy. Proc Natl Acad Sci 97: 865-870.

Liu X, Bolteus AJ, Balkin DM, Henschel O, Bordey A. 2006. GFAP-expressing cells in the postnatal subventricular zone display a unique glial phenotype intermediate between radial glia and astrocytes. Glia 54: 394-410.

Liu HK, Belz T, Bock D, Takacs A, Wu H, Lichter P, Chai M, Schutz G. 2008. The nuclear receptor tailless is required for neurogenesis in the adult subventricular zone. Genes Dev 22: 2473-2478.

Liu HK, Wang Y, Belz T, Bock D, Takacs A, Radlwimmer B, Barbus S, Reifenberger G, Lichter P, Schutz G. 2010. The nuclear receptor tailless induces long-term neural stem cell expansion and brain tumor initiation. Genes Dev 24: 683-695.

Lledo PM, Merkle FT, Alvarez-Buylla A. 2008. Origin and function of olfactory bulb interneuron diversity. Trends Neurosci 31: 392-400.

Lois C, Garcia-Verdugo JM, Alvarez-Buylla A. 1996. Chain migration of neuronal precursors. Science 271: 978-981.

Lugert S, Basak O, Knuckles P, Haussler U, Fabel K, Gotz M, Haas CA, Kempermann G, Taylor V, Giachino C. 2010. Quiescent and active hippocampal neural stem cells with distinct morphologies respond selectively to physiological and pathological stimuli and aging. Cell Stem Cell 6: 445-456.

Ma DK, Ming GL, Song H. 2005. Glial influences on neural stem cell development: Cellular niches for adult neurogenesis. Curr Opin Neurobiol 15: 514-520.

Ma DK, Jang MH, Guo JU, Kitabatake Y, Chang ML, PowAnpongkul N, Flavell RA, Lu B, Ming GL, Song H. 2009. Neuronal activity-induced Gadd45b promotes epigenetic DNA demethylation and adult neurogenesis. Science 323: 1074-1077.

Ma DK, Marchetto MC, Guo JU, Ming GL, Gage FH, Song H. 2010. Epigenetic choreographers of neurogenesis in the adult mammalian brain. Nat Neurosci 13: 1338-1344.

Maekawa M, Takashima N, Arai Y, Nomura T, Inokuchi K, Yuasa S, Osumi N 2005. Pax6 is required for production and maintenance of progenitor cells in postnatal hippocampal neurogenesis. Genes Cells 10: 1001-1014.

Mandel G, Fiondella CG, Covey MV, Lu DD, Loturco JJ, Ballas N. 2011. Repressor element 1 silencing transcription factor (REST) controls radial migration and temporal neuronal specification during neocortical development. Proc Natl Acad Sci 108: 16789-16794.

Mangin JM, Gallo V. 2011. The curious case of NG2 cells: Transient trend or game changer? ASN Neuro 3: e00052. doi: 10.1042/AN20110001.

Marchetto MC, Carromeu C, Acab A, Yu D, Yeo GW, Mu Y, Chen G, Gage FH, Muotri AR. 2010. A model for neural development and treatment of Rett syndrome using human induced pluripotent stem cells. Cell 143: 527-539.

Marshall CA, Goldman JE. 2002. Subpallial dlx2-expressing cells give rise to astrocytes and oligodendrocytes in the cerebral cortex and white matter. I Neurosci 22: 9821-9830.

Marshall CA, Novitch BG, Goldman JE. 2005. Olig2 directs astrocyte and oligodendrocyte formation in postnatal subventricular zone cells. J Neurosci 25: 7289-7298. 
McConnell SK. 1989. The determination of neuronal fate in the cerebral cortex. Trends Neurosci 12: 342-349.

Menn B, Garcia-Verdugo JM, Yaschine C, Gonzalez-Perez O, Rowitch D, Alvarez-Buylla A. 2006. Origin of oligodendrocytes in the subventricular zone of the adult brain. J Neurosci 26: 7907-7918.

Mercier F, Kitasako JT, Hatton GI. 2002. Anatomy of the brain neurogenic zones revisited: Fractones and the fibroblast/ macrophage network. J Comp Neurol 451: 170-188.

Merkle FT, Tramontin AD, Garcia-Verdugo JM, Alvarez-Buylla A. 2004. Radial glia give rise to adult neural stem cells in the subventricular zone. Proc Natl Acad Sci 101: 17528-17532.

Merkle FT, Mirzadeh Z, Alvarez-Buylla A. 2007. Mosaic organization of neural stem cells in the adult brain. Science 317: 381-384.

Ming GL, Song H. 2005. Adult neurogenesis in the mammalian central nervous system. Annu Rev Neurosci 28: 223-250.

Ming GL, Song H. 2011. Adult neurogenesis in the mammalian brain: Significant answers and significant questions. Neuron 70: 687-702.

Mira H, Andreu Z, Suh H, Lie DC, Jessberger S, Consiglio A, San Emeterio J, Hortiguela R, Marques-Torrejon MA, Nakashima K, et al. 2010. Signaling through BMPR-IA regulates quiescence and long-term activity of neural stem cells in the adult hippocampus. Cell Stem Cell 7: 78-89.

Mirzadeh Z, Merkle FT, Soriano-Navarro M, Garcia-Verdugo JM, Alvarez-Buylla A. 2008. Neural stem cells confer unique pinwheel architecture to the ventricular surface in neurogenic regions of the adult brain. Cell Stem Cell 3: 265-278.

Molofsky AV, Pardal R, Iwashita T, Park IK, Clarke MF, Morrison SJ. 2003. Bmi-1 dependence distinguishes neural stem cell self-renewal from progenitor proliferation. Nature 425: 962-967.

Morrens J, Van Den Broeck W, Kempermann G. 2012. Glial cells in adult neurogenesis. Glia 60: 159-174.

Mouret A, Lepousez G, Gras J, Gabellec MM, Lledo PM. 2009. Turnover of newborn olfactory bulb neurons optimizes olfaction. J Neurosci 29: 12302-12314.

Mu Y, Lee SW, Gage FH. 2010. Signaling in adult neurogenesis. Curr Opin Neurobiol 20: 416-423.

$\mathrm{Mu} \mathrm{L}$, Berti L, Masserdotti G, Covic M, Michaelidis TM Doberauer K, Merz K, Rehfeld F, Haslinger A, Wegner M, et al. 2012. SoxC transcription factors are required for neuronal differentiation in adult hippocampal neurogenesis. J Neurosci 32: 3067-3080.

Nam HS, Benezra R. 2009. High levels of Id1 expression define B1 type adult neural stem cells. Cell Stem Cell 5: 515-526.

Nguyen-Ba-Charvet KT, Picard-Riera N, Tessier-Lavigne $M$, Baron-Van Evercooren A, Sotelo C, Chedotal A. 2004. Multiple roles for slits in the control of cell migration in the rostral migratory stream. I Neurosci 24: 1497-1506.

Niu W, Zou Y, Shen C, Zhang CL. 2011. Activation of postnatal neural stem cells requires nuclear receptor TLX. I Neurosci 31: 13816-13828.

Noctor SC, Martinez-Cerdeno V, Kriegstein AR 2007. Neural stem and progenitor cells in cortical development. Novartis Found Symp 288: 59-78.

Nomura T, Goritz C, Catchpole T, Henkemeyer M, Frisen J. 2010. EphB signaling controls lineage plasticity of adult neural stem cell niche cells. Cell Stem Cell 7: 730-743.

Noonan MA, Bulin SE, Fuller DC, Eisch AJ. 2010. Reduction of adult hippocampal neurogenesis confers vulnerability in an animal model of cocaine addiction. I Neurosci 30: 304-315.

Okano H, Temple S. 2009. Cell types to order: Temporal specification of CNS stem cells. Curr Opin Neurobiol 19: 112-119.
Palmer TD, Willhoite AR, Gage FH. 2000. Vascular niche for adult hippocampal neurogenesis. J Comp Neurol 425: 479-494.

Parent JM, Jessberger S, Gage FH, Gong C. 2007. Is neurogenesis reparative after status epilepticus? Epilepsia 48: 69-71.

Parras CM, Galli R, Britz O, Soares S, Galichet C, Battiste J, Johnson JE, Nakafuku M, Vescovi A, Guillemot F. 2004. Mash1 specifies neurons and oligodendrocytes in the postnatal brain. EMBO J 23: 4495-4505.

Petrik D, Lagace DC, Eisch AJ. 2012. The neurogenesis hypothesis of affective and anxiety disorders: Are we mistaking the scaffolding for the building? Neuropharmacology 62: $21-34$.

Pleasure SJ, Collins AE, Lowenstein DH. 2000. Unique expression patterns of cell fate molecules delineate sequential stages of dentate gyrus development. I Neurosci 20: 60956105.

Renault VM, Rafalski VA, Morgan AA, Salih DA, Brett JO, Webb AE, Villeda SA, Thekkat PU, Guillerey C, Denko NC, et al. 2009. FoxO3 regulates neural stem cell homeostasis. Cell Stem Cell 5: 527-539.

Reynolds BA, Weiss S. 1992. Generation of neurons and astrocytes from isolated cells of the adult mammalian central nervous system. Science 255: 1707-1710.

Robel S, Berninger B, Gotz M. 2011. The stem cell potential of glia: Lessons from reactive gliosis. Nat Rev Neurosci 12: 88-104.

Rohatgi R, Milenkovic L, Scott MP. 2007. Patched1 regulates hedgehog signaling at the primary cilium. Science 317: 372-376.

Roybon L, Deierborg T, Brundin P, Li JY. 2009a. Involvement of Ngn2, Tbr and NeuroD proteins during postnatal olfactory bulb neurogenesis. Eur I Neurosci 29: 232-243.

Roybon L, Hjalt T, Stott S, Guillemot F, Li JY, Brundin P. 2009b. Neurogenin2 directs granule neuroblast production and amplification while NeuroD1 specifies neuronal fate during hippocampal neurogenesis. PLOS ONE 4: e4779. doi: 10.1371/journal.pone.0004779.

Sabin LR, Zhou R, Gruber JJ, Lukinova N, Bambina S, Berman A, Lau CK, Thompson CB, Cherry S. 2009. Ars2 regulates both miRNA- and siRNA-dependent silencing and suppresses RNA virus infection in Drosophila. Cell 138: 340-351.

Sahay A, Wilson DA, Hen R. 2011. Pattern separation: A common function for new neurons in hippocampus and olfactory bulb. Neuron 70: 582-588.

Sakamoto M, Imayoshi I, Ohtsuka T, Yamaguchi M, Mori K, Kageyama R. 2011. Continuous neurogenesis in the adult forebrain is required for innate olfactory responses. Proc Natl Acad Sci 108: 8479-8484.

Sanai N, Nguyen T, Ihrie RA, Mirzadeh Z, Tsai HH, Wong M, Gupta N, Berger MS, Huang E, Garcia-Verdugo JM, et al. 2011. Corridors of migrating neurons in the human brain and their decline during infancy. Nature 478: 382-386.

Sawamoto K, Wichterle H, Gonzalez-Perez O, Cholfin JA, Yamada M, Spassky N, Murcia NS, Garcia-Verdugo JM, Marin O, Rubenstein JL, et al. 2006. New neurons follow the flow of cerebrospinal fluid in the adult brain. Science 311: 629-632.

Scheffler B, Walton NM, Lin DD, Goetz AK, Enikolopov G, Roper SN, Steindler DA. 2005. Phenotypic and functional characterization of adult brain neuropoiesis. Proc Natl Acad Sci 102: 9353-9358.

Seri B, Garcia-Verdugo JM, McEwen BS, Alvarez-Buylla A. 2001. Astrocytes give rise to new neurons in the adult mammalian hippocampus. J Neurosci 21: 7153-7160.

Shen Q, Goderie SK, Jin L, Karanth N, Sun Y, Abramova N, Vincent P, Pumiglia K, Temple S. 2004. Endothelial cells stimulate self-renewal and expand neurogenesis of neural stem cells. Science 304: 1338-1340. 
Shen L, Nam HS, Song P, Moore H, Anderson SA. 2006. FoxG1 haploinsufficiency results in impaired neurogenesis in the postnatal hippocampus and contextual memory deficits. Hippocampus 16: 875-890.

Shen Q, Wang Y, Kokovay E, Lin G, Chuang SM, Goderie SK, Roysam B, Temple S. 2008. Adult SVZ stem cells lie in a vascular niche: A quantitative analysis of niche cell-cell interactions. Cell Stem Cell 3: 289-300.

Snapyan M, Lemasson M, Brill MS, Blais M, Massouh M, Ninkovic J, Gravel C, Berthod F, Gotz M, Barker PA, et al. 2009. Vasculature guides migrating neuronal precursors in the adult mammalian forebrain via brain-derived neurotrophic factor signaling. I Neurosci 29: 4172-4188.

Snyder JS, Soumier A, Brewer M, Pickel J, Cameron HA. 2011. Adult hippocampal neurogenesis buffers stress responses and depressive behaviour. Nature 476: 458-461.

Soldati C, Bithell A, Johnston C, Wong KY, Teng SW, Beglopoulos V, Stanton LW, Buckley NJ. 2012. Repressor element 1 silencing transcription factor couples loss of pluripotency with neural induction and neural differentiation. Stem Cells 30: 425-434.

Song H, Stevens CF, Gage FH. 2002. Astroglia induce neurogenesis from adult neural stem cells. Nature 417: 39-44.

Spassky N, Merkle FT, Flames N, Tramontin AD, GarciaVerdugo JM, Alvarez-Buylla A. 2005. Adult ependymal cells are postmitotic and are derived from radial glial cells during embryogenesis. I Neurosci 25: 10-18.

Steiner B, Klempin F, Wang L, Kott M, Kettenmann H, Kempermann G. 2006. Type-2 cells as link between glial and neuronal lineage in adult hippocampal neurogenesis. Glia 54: 805-814.

Suh H, Consiglio A, Ray J, Sawai T, D'Amour KA, Gage FH. 2007. In vivo fate analysis reveals the multipotent and selfrenewal capacities of $\mathrm{Sox}^{+}$neural stem cells in the adult hippocampus. Cell Stem Cell 1: 515-528.

Sun G, Yu RT, Evans RM, Shi Y. 2007. Orphan nuclear receptor TLX recruits histone deacetylases to repress transcription and regulate neural stem cell proliferation. Proc Natl Acad Sci 104: 15282-15287.

Sun J, Ming GL, Song H. 2011. Epigenetic regulation of neurogenesis in the adult mammalian brain. Eur I Neurosci 33: 1087-1093.

Takahashi K, Yamanaka S. 2006. Induction of pluripotent stem cells from mouse embryonic and adult fibroblast cultures by defined factors. Cell 126: 663-676.

Tavazoie M, Van der Veken L, Silva-Vargas V, Louissaint M, Colonna L, Zaidi B, Garcia-Verdugo JM, Doetsch F. 2008. A specialized vascular niche for adult neural stem cells. Cell Stem Cell 3: 279-288.

Tozuka Y, Fukuda S, Namba T, Seki T, Hisatsune T. 2005. GABAergic excitation promotes neuronal differentiation in adult hippocampal progenitor cells. Neuron 47: 803-815.

van Praag H, Christie BR, Sejnowski TJ, Gage FH. 1999. Running enhances neurogenesis, learning, and long-term potentiation in mice. Proc Natl Acad Sci 96: 13427-13431.

van Praag H, Schinder AF, Christie BR, Toni N, Palmer TD, Gage FH. 2002. Functional neurogenesis in the adult hippocampus. Nature 415: 1030-1034.

Wang TW, Stromberg GP, Whitney JT, Brower NW, Klymkowsky MW, Parent JM. 2006. Sox3 expression identifies neural progenitors in persistent neonatal and adult mouse forebrain germinative zones. I Comp Neurol 497: 88-100.

Wang C, Liu F, Liu YY, Zhao CH, You Y, Wang L, Zhang J, Wei B, Ma T, Zhang Q, et al. 2011. Identification and characterization of neuroblasts in the subventricular zone and rostral migratory stream of the adult human brain. Cell Res 21: 1534-1550.
Weber P, Metzger D, Chambon P. 2001. Temporally controlled targeted somatic mutagenesis in the mouse brain. Eur J Neurosci 14: 1777-1783.

Whitman MC, Fan W, Rela L, Rodriguez-Gil DJ, Greer CA. 2009. Blood vessels form a migratory scaffold in the rostral migratory stream. J Comp Neurol 516: 94-104.

Winpenny E, Lebel-Potter M, Fernandez ME, Brill MS, Gotz M, Guillemot F, Raineteau O. 2011. Sequential generation of olfactory bulb glutamatergic neurons by Neurog2-expressing precursor cells. Neural Dev 6: 12. doi: 10.1186/1749-8104-6-12.

Yamada Y, Aoki H, Kunisada T, Hara A. 2010. Rest promotes the early differentiation of mouse ESCs but is not required for their maintenance. Cell Stem Cell 6: 10-15.

Yang L, Liu Z, Lu F, Dong A, Huang H. 2006. SERRATE is a novel nuclear regulator in primary microRNA processing in Arabidopsis. Plant J 47: 841-850.

Zhang CL, Zou Y, He W, Gage FH, Evans RM. 2008. A role for adult TLX-positive neural stem cells in learning and behaviour. Nature 451: 1004-1007.

Zhao C, Teng EM, Summers RG Jr, Ming GL, Gage FH. 2006. Distinct morphological stages of dentate granule neuron maturation in the adult mouse hippocampus. I Neurosci 26: $3-11$.

Zhao T, Zhang ZN, Rong Z, Xu Y. 2011. Immunogenicity of induced pluripotent stem cells. Nature 474: 212-215. 


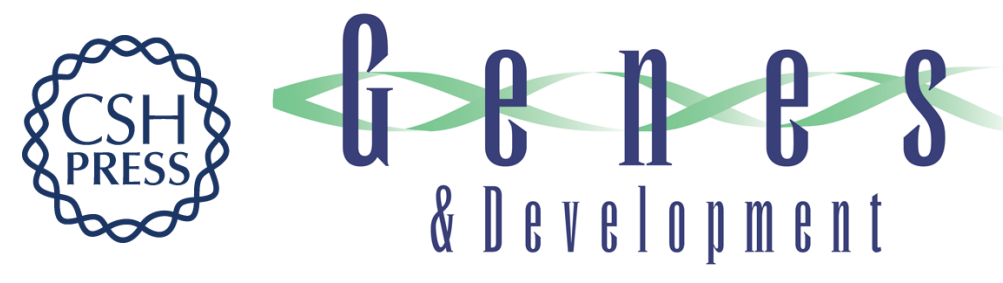

\section{Orchestrating transcriptional control of adult neurogenesis}

Jenny Hsieh

Genes Dev. 2012, 26:

Access the most recent version at doi:10.1101/gad.187336.112

References This article cites 155 articles, 53 of which can be accessed free at: http://genesdev.cshlp.org/content/26/10/1010.full.html\#ref-list-1

License

Email Alerting Receive free email alerts when new articles cite this article - sign up in the box at the top Service right corner of the article or click here.

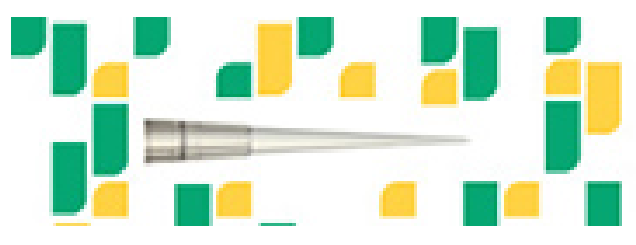

Focused on your science. 